\title{
EFL Pre-Service Teachers' Perception Toward Process Approach in Teaching Writing at SMP Negeri 2 Banjar
}

\author{
I Ketut Putra Pradnyana ${ }^{1}$ \\ Universitas Pendidikan Ganesha, Indonesia \\ excitedputrapradnyana17@gmail.com \\ Ni Luh Putu Eka Sulistia Dewi ${ }^{2}$ \\ Universitas Pendidikan Ganesha, Indonesia \\ sulistia.dewi@undiksha.ac.id \\ Dewa Ayu Eka Agustini ${ }^{3}$ \\ Universitas Pendidikan Ganesha, Indonesia \\ eka.agustini@undiksha.ac.id
}

\begin{abstract}
The current study was intended to identify the English Foreign Language (EFL) pre-service teachers' perception toward process approach in teaching writing at SMP Negeri 2 Banjar. This study was a basic interpretative study. In collecting the data, this study used questionnaire and interview. The study was followed by 5 preservice teachers at SMP Negeri 2 Banjar. The data from the questionnaire were analyzed descriptively and the data from the interview were analyzed using O'Connor and Gibson's guidance. The study found that the teachers have positive and very positive perception towards process approach in teaching writing. It was also found that during the implementation of process approach, the teachers were aware of several challenges encountered, namely the limitations of students in developing ideas, weaknesses of students in aspects of language and students requires times to finish writing. This study concludes that the pre-service English teachers had a positive perception towards using process approach in teaching writing.
\end{abstract}

Keywords: EFL, Perception, Pre-Service Teacher, Process Approach

\section{INTRODUCTION}

Writing has some important roles in conveying ideas and concept. As stated by Keshta and Harb (2013), writing is a necessary thing in everyday lives such in business, creativity, and in scholarly pursuits. Langan (2001) supports that there are two reasons why writing skill is very important. The reasons are that, first, writing ability is a basic need for English learners to support their academic success. English learners are often asked to do written assignment and their English competence can also be seen from their writing performance. Second, English writing skill is a practical need to support their future carrier. Since writing is taught from earlier stage of learning in Indonesia, teachers need to implement effective teaching strategies in order to make the students able to convey their ideas and concept through writing.

In learning to write, the role of teacher is important during the process. Marhaeni and Dantes (2014) states that in order to maximize the students' writing, teacher need to view that writing is a systematic and gradual process. Writing is 
believed as a creative act that requires time as well as suggestions and criticism to produce better results (Sun \& Feng, 2009). In the writing process, the teacher is not someone who gives the topic to students and evaluates the final product without being involved in the writing process itself. Brown (2004) argues that writing reflects a thought. With the writing process approach, students become more aware of themselves, and find ways to produce writing.

The reason of emphasizing the use of process approach is because of students' low writing achievement is due to lack of process. Eliwarti and Maarof (2014) state that the use of product approach gives little role in process of producing writing such as planning, drafting, revising, etc. Besides that, the product approach is criticized because it is no longer suitable with the current learning situation that is focusing on individual learning and processes of the mind rather than product (Palpanadan et al., 2014). The use of process writing approach is recommended for teaching writing because it is important that the teacher gives comment and suggestions to improve the quality of writing. The teacher should guide the students during the process of writing.

A preliminary observation was conducted in SMP N 2 Banjar. EFL Preservice teachers claimed that in teaching writing, they applied process approach to the students. During the teaching writing, the EFL pre-service teachers said that they helped the students in each of the stages of writing starts from developing ideas, making draft, doing revisions and publishing their writings to social media or to peers. They also claimed that students' show better writing performance. It is interesting to see the teacher's perception of the implementation of the process approach in teaching writing.

This study investigates the EFL pre-service teachers' perception toward process approach in teaching writing. The study is carried out in SMP N 2 Banjar. In conducting the study, EFL pre-service teacher are given questionnaire and interviewed.

\section{METHOD}

Design

The current study is explanatory sequential mix method research. An explanatory sequential mix method research provides a brief information through quantitative and/or qualitative data collection towards particular situation or phenomenon (Subedi, 2016). The study focuses to identify the EFL pre-service teacher perception toward PA in teaching writing and the challenges faced by teacher in teaching writing using PA.

\section{Participants}

The participant refers to the informant of the study. The informant in this study were 5 EFL pre-service teacher who had used PA in teaching writing at SMP N 2 Banjar Buleleng Bali.

\section{Instruments}

In gathering the data, the study employed questionnaire and interview. A questionnaire was aimed to identify pre-service teachers' perception towards PA in teaching writing. The type of questionnaire in this study used Likert-type questionnaire. The questionnaire focused on (1) the writing as a process, and (2) improvement on students' writing competency. 
The Art of Teaching English as a Foreign Language, Vol.1 No.2 2020

p-ISSN : 2656-8942, e-ISSN : 2684-8546

DOI: $10.36663 /$ tatefl.v1i2.80

Data Analysis

The data from the questionnaire were analyzed descriptively and the data from the interview were analyzed using O'Connor and Gibson's guidance

\section{FINDINGS \& DISCUSSIONS}

The purpose of the questionnaire was to identify the perception of EFL preservice teachers toward PA. After doing quantitative analysis, the result can be seen in Table 1.

\begin{tabular}{ccc} 
Teacher & $\begin{array}{c}\text { Table 1 Result of Questionnaire } \\
\text { Sum of Questionnaire }\end{array}$ & Category \\
\hline 1 & 91 & Positive \\
\hline 2 & 98 & Very Positive \\
\hline 3 & 94 & Very Positive \\
\hline 4 & 93 & Very Positive \\
\hline 5 & 90 & Positive \\
\hline Average & 93.2 & Very Positive
\end{tabular}

From Table 1, it can be seen that the teachers have positive and very positive perception towards PA in teaching writing. Overall, the average score of teachers' perceptions is 93.2 which belongs to very positive category. This indicates that the pre-service teachers having a good knowledge of the concept and the implementation of teaching writing using PA.

To dig more information of pre-service teachers' perception towards PA, an interview was conducted. From the result of interviews, there are several themes that can be taken from concept of the $P A$, reasons for using $P A$, implementation of PA, benefits of using PA, and obstacles in implementing PA in teaching writing skills to students. Table 2 will present the answers given by the teacher regarding the concept $P A$.

\section{Table 2 Concept of $P A$}

\begin{tabular}{cl} 
Teacher & \multicolumn{1}{c}{ Answer } \\
\hline 1 & $\begin{array}{l}\text { an approach that prioritizes the process rather than the product. In } \\
\text { teaching writing, we can see the progress of students during the } \\
\text { process they learn to produce writing Learn in a guidance from the } \\
\text { teacher, especially in writing skills }\end{array}$ \\
\hline 2 & $\begin{array}{l}\text { What I know about the PA is an approach that the process needs to be } \\
\text { emphasized in making a product. It will also focus on the steps taken to } \\
\text { complete a product (in terms of writing). }\end{array}$ \\
\hline 3 & $\begin{array}{l}\text { The PA emphasizes the process students go through in writing, so that } \\
\text { assessment is not emphasized on the results of the writing, but on the } \\
\text { stages that are passed }\end{array}$ \\
\hline 5 & $\begin{array}{l}\text { Teaching students, the process of writing in English by providing } \\
\text { guidance in the steps of writing that need to be followed to produce a } \\
\text { good writing }\end{array}$ \\
\hline $\begin{array}{l}\text { An approach that emphasizes the stages students need to follow during } \\
\text { the writing learning process. These stages will be able to help students } \\
\text { to understand and prepare in writing }\end{array}$
\end{tabular}

From Table 1, the theme that can be drawn is that the teachers see PA emphasizes process rather than product. The teachers said: 
"An approach that prioritizes the process rather than the product" ( $\mathrm{T} 1)$ "Emphasizes the processes students go through in writing" (T3)

"Providing guidance in the steps of writing" (T4)

From the teacher's answers about the concept of the PA, they said that the PA is a way of teaching writing skills that emphasizes process over final product. The teaching writing is done by providing ongoing guidance. According to the teachers' answer, the assessment is not based on the final product. Table 3 will present the teachers' answers related with the reason of implementing PA in teaching writing.

\section{Table 3 The Reason Implementing PA}

\begin{tabular}{cl} 
Teacher & \multicolumn{1}{c}{ Answer } \\
\hline 1 & $\begin{array}{l}\text { the PA provides guidance to students so students become more } \\
\text { comfortable in writing }\end{array}$ \\
\hline 2 & $\begin{array}{l}\text { Because in writing there are several criteria that must be achieved by } \\
\text { students. If students do not follow the steps in the writing process there } \\
\text { will be many things that do not appear in the final results of student } \\
\text { writing }\end{array}$ \\
\hline 3 & $\begin{array}{l}\text { The PA can simplify writing activities undertaken by students. For } \\
\text { example, they become aware of the topics they need to explore, or } \\
\text { important points they can develop from a main topic. The PA not only } \\
\text { helps students to produce good writing, but also slowly gives them an } \\
\text { understanding that writing is a process in which the abilities, } \\
\text { implementation and results are obtained in stages. }\end{array}$ \\
\hline 4 & $\begin{array}{l}\text { The PA can make students write good writing. Because, using this } \\
\text { approach, writing will be organized through the steps }\end{array}$ \\
\hline 5 & The PA can provide more authentic evidence of student development.
\end{tabular}
process

From Table 3, the teachers believed that using PA teaches writing through

"PA provides guidance to students so students become more comfortable in writing" (T1)

"The PA not only helps students to produce good writing, but also slowly gives them an understanding that writing is a process in which the abilities, implementation and results are obtained in stages" (T3)

"Using this approach, writing will be organized through the steps" (T4)

Developing a good writing, students must go through several stages ranging from drafting to publishing. The stages in writing will also help in improving the quality of student writing. Using a PA will also make the learning process of writing organized. During the pre-service teaching time, the teachers said that they had implemented PA in teaching writing. The implementation is transcribed in Table 4.

\begin{tabular}{|c|c|}
\hline Teacher & Answer \\
\hline 1 & $\begin{array}{l}\text { - First, I explain to students using a simple and fun concept map, about } \\
\text { the steps to make a writing } \\
\text { - I ask students to prepare their writing equipment, and ask that they } \\
\text { prepare to start writing } \\
\text { - Invite students to determine a the idea, after each student can get an }\end{array}$ \\
\hline
\end{tabular}


idea, then invite students to start writing

- Asking for products that have been written for inspection with friends next to them, assisted by the teacher together

- After completing the assignment, the teacher will collect assess which part is wrong, and which part the friend forgot to correct.

- Return students' writing and ask students to revise until the final product is reached

\begin{tabular}{cl}
\hline 2 & The application is carried out by providing material related to the \\
expected output. Then students are assigned to start their writing and \\
given feedback \\
Making draft. First the brainstorming process about the writing topic that \\
will be developed then asked the students do develop a draft. \\
Giving suggestions on students' writing draft related with grammar, \\
vocabulary. This can be done also by self-check, pair check. \\
The students revise their draft based on suggestions given \\
Second revision from comments and suggestions \\
Final product is published. \\
Prewriting \\
In pre-writing, I ask the students to make a draft about a certain topic. \\
Topic development is very important. The topic assembles all parts of \\
the writing into one wholeness. \\
Students gather various information through interviews. So at this stage, \\
students make as many questions as possible in their notebooks, then \\
conduct interviews. The information they get is then read one by one, \\
then with guidance, they break down the information into small groups \\
for later written into writing framework. \\
Writing \\
Students at this stage begin to develop their ideas by utilizing \\
information that is already in the framework of their writing. They try to \\
make an interesting beginning of writing, compile the contents and make \\
a memorable ending. \\
Post \\
At this stage, students conduct an initial evaluation process. They can \\
ask for advice and opinions from the teacher or friend. \\
The results of the initial evaluation serve as material for revision of the \\
writing before it is finally published \\
In pre writing, students will be invited to brainstorm about the theme \\
they will write. At this stage students will also be introduced to \\
vocabulary related to the theme they will write. During writing, students \\
will write according to the theme given. Students can ask their friends to \\
review the results of their writing. Post writing, students will show the \\
results of their writing, then other students will respond to the work of \\
their friends. Can be verbal, and can be in writing
\end{tabular}

From Table 4, it can be seen that the teachers in teaching writing is done through stages. In general, the way the teachers implement the PA in teaching writing is almost the same. Starting from the process of making a draft that was previously the process of gathering information about the topic of writing carried out. After that the process of reviewing the results of student writing is done. The review process can be carried out by the teacher or colleague by giving criticism and suggestions to student writing. Students then revise their writing according to the results of the review before publishing it. 
During PA implementation, the teacher sees many benefits for students, especially in the development of student writing. Table 5 presents the results of interviews about the benefits of implementing the PA.

\begin{tabular}{|c|c|}
\hline Teacher & Answer \\
\hline 1 & $\begin{array}{l}\text { I think that the approach process has several benefits, including: } \\
\text { students can create ideas in writing, students can create writing in an } \\
\text { organized manner, students can learn from mistakes they made and } \\
\text { improved their writing }\end{array}$ \\
\hline 2 & $\begin{array}{l}\text { first, students can learn at their own pace. Secondly, this technique } \\
\text { allows me to track difficulties experienced by students, so that they can } \\
\text { be used as considerations in teaching. This technique also teaches } \\
\text { students to keep trying before achieving the desired }\end{array}$ \\
\hline 3 & $\begin{array}{l}\text { Students have an idea of what to do first when they start writing so they } \\
\text { don't get confused about what to write, then continue the process so } \\
\text { they get quality results } \\
\text { Students also learn that their writing can reach a better version through } \\
\text { the process of correction (self check, pair check, teacher check) as well } \\
\text { as students learn how to correct their writing in the future. }\end{array}$ \\
\hline 4 & $\begin{array}{l}\text { Students are more active, trained to think critically and have a more } \\
\text { inherent writing experience that helps them in future writing activities. } \\
\text { Students become more confident because their writing can be even } \\
\text { better after revisions. } \\
\text { The activity of correcting friends' writing is also a good learning for } \\
\text { students to master more basic points such as sentence structure, use of } \\
\text { tenses or grammar and the use of proper punctuation. }\end{array}$ \\
\hline 5 & $\begin{array}{l}\text { Students can improve their writing during the writing process, until they } \\
\text { can produce the desired writing }\end{array}$ \\
\hline
\end{tabular}

In Table 5 the teachers see the benefit of teaching writing through PA.

"Students can create ideas in writing, students can create writing in an organized manner, students can learn from mistakes they made and improved their writing" (T1)

"Students also learn that their writing can reach a better version through the process of correction" (T3)

"Students are more active, trained to think critically and have a more inherent writing experience" (T4)

They believed that the feedback given in writing process improves writing quality. The benefits of the development of student writing according to the teacher occur because of the input and suggestions from either friends or teachers. This evaluation process gives students an idea of the shortcomings of their writing so that they are motivated to improve. In addition, the use of the PA not only teaches the writing process, but also teaches the value that maximum results can only be achieved through a process. Table 6 presents the Challenges of Implementing PA.

Table 6 The Challenges of Implementing PA 


\begin{tabular}{cl}
\hline Teacher & \multicolumn{1}{c}{ Answer } \\
\hline 1 & $\begin{array}{l}\text { Based on my experience using the PA when writing, the obstacle that I } \\
\text { found was in the difficulty of students determining their ideas. So } \\
\text { students have to use 1 topic in order to make it easier to develop } \\
\text { speech. In addition, difficulties exist at the writing stage. Students tend } \\
\text { to have difficulty in developing paragraphs. Finally, there is the } \\
\text { correcting stage. Many students experience errors in writing aspects, } \\
\text { especially in grammar and spelling. But in the correcting stage students } \\
\text { can learn together to correct, and reflect on their mistakes in writing, so } \\
\text { that in the future can produce a better product. }\end{array}$ \\
$\begin{array}{l}\text { Students still often feel inferior if experiencing difficulties. When they find } \\
\text { their friend has mastered one thing, these students tend to feel left } \\
\text { behind and are not motivated in learning }\end{array}$ \\
$\begin{array}{l}\text { When doing a pair check, not all students have a good concept so when } \\
\text { correcting other people's writing, they do not know whether the } \\
\text { corrected writing is correct or not and do not know how to correct it. So } \\
\text { most students at this level will not find fault with their friend's writing and } \\
\text { say if the writing is correct. } \\
\text { Students whose English proficiency is still lacking difficulty in composing } \\
\text { sentences. Limited vocabulary makes the sentence less elaborative. } \\
\text { Many students don't understand the importance of keeping the whole } \\
\text { story interesting and connected. For example, the story at the beginning } \\
\text { is good but the ending is not logical. }\end{array}$ \\
\hline $\begin{array}{l}\text { The teacher needs several meetings to explain and complete a writing } \\
\text { with students. Students need a long time to finish writing. }\end{array}$ \\
\hline $\begin{array}{l}\text { Short student focus. During the process, the teacher must continue to } \\
\text { control student attention so that the process runs optimally. }\end{array}$
\end{tabular}

The challenges were to help the students to elaborate the topic and time to finish Writing.

"Students whose English proficiency is still lacking difficulty in composing sentences. Limited vocabulary makes the sentence less elaborative" (T3)

"teacher needs several meetings to explain and complete a writing with students" (T4)

Challenges experienced by students were choosing and elaborating a topic. Sometimes the teacher must determine the topic for students to speed up the writing process. The other challenge is the process of revision by pair. When the correction process with friends, sometimes knowledge about aspects of language becomes a barrier. Students sometimes do not know what is right and wrong in a friend's writing. In addition, the use of the PA is very time consuming. Requires several meetings to complete one paper.

The teachers had the same perception about the concept of the PA in teaching writing skills to students. In general, the teacher understands the PA as a mechanism of writing teaching throughout stages. The teacher's perception is in accordance with the concept of the PA in teaching writing skills. In the application of the PA, students with teacher guidance will follow the stages of writing starting from making a draft, making revisions, and publishing the results of the writing (Bayat, 2014). The emphasis is based on the understanding that completing writing is a complex process that cannot be completed at one time. Marhaeni and 
Dantes (2014) supports that writing is a long process developed systematically and gradually.

Looking at the opinions of teachers about the reasons for using the PA, Miftah (2015) explains that writing is a skill that is challenging to master by students. Therefore, PA is needed in teaching writing skills. The teacher must be able to guide students in each of these stages so that students feel encouraged to master the ability to write (Faraj, 2015). In addition, the reason teachers use the PA in teaching writing is to make students comfortable. As the teacher said:

Sometimes should not discourage the studies to make the process more challenging for students. The use of the PA is recommended because it can reduce student anxiety during the writing process (Arici \& Kaldirim, 2015). This is because in each stage of writing, students get input and suggestions from both the teacher and friends who motivate them to further develop their writing. In implementing the PA in teaching writing, the teacher has his own way of adjusting to the stages in writing. The first step taken by the teacher is gathering information about the topic to be discussed. This information gathering process is important to enrich the students' knowledge about particular topic (Asriati \& Maharida, 2013). After that, the information obtained is developed into a draft. The draft paper is then consulted with the teacher or friend. Suggestions and input received by students are then applied to student drafts. At this revision stage, teachers and students can provide input on language components such as grammar and vocabulary (Vonna et al., 2015). In addition, the teacher can also provide input on the elaboration of the paragraph which is considered still lacking in broad discussion.

The teacher also sees several benefits in the implementation of the PA especially for students. Students' writing abilities become better as the PA is implemented. Some research results also found that students' writing ability improved after the PA was implemented. Carolan and Kyppö (2015) found that students who learn to write on the PA show higher scores than students who learn on the product approach. Alodwan and Ibnian (2014) also identified that students' essay writing was improved after PA is implemented. This is inseparable from the revision process given by the teacher or friend. Besides the benefits expressed by the teacher is the PA helps students to think critically and be able to provide corrections to errors or deficiencies in another student work.

This is in line with opinions raised by Hadzhikoleva et al., (2019) who say that the correction process by friends or can be said as part of a pair-assessment helps students to think critically when facing problem and be able to find solutions. Besides that, the framework of PA focuses on how to revise in response to feedback from the reader (Asriati \& Maharida, 2013). It could be teacher, pair or the writer himself. Despite of their understanding of concept and implementation of PA in teaching writing, they still faced challenges. The challenges were students' inability to explore ideas or topic so the teachers need to guide them every time. Thus, using PA is quite time consuming. Adula (2018) states that the teacher needed a long time to carefully read the students' draft one by one. The revision process if only carried out by the teacher alone, will require several meetings to complete a paper. Palpanadan et al., (2014) state that in teaching writing using PA, time management play crucial roles.

In general, writing ability is very difficult to master because of the limited or lack of ability of students to develop a topic and make a coherent paragraph. 
According to Genlott and Grönlund (2013) this weakness is based on the low literacy and lack of interest in reading. In addition, Pratiwi et al., (2016) said that the limitations of students in understanding language components such as grammar and vocabulary are becoming problems in writing process. In making revisions through pair, the teacher should be present in giving direction on what and how to correct. Teachers are advised to make an assessment guide for students so that students are able in providing input and suggestions to other students (Steinke \& Fitch, 2017). This guide is also useful to reduce bias in the pair assessment process on student writing.

\section{CONCLUSION}

This study concludes that the teachers have a very positive perception towards process approach in teaching writing. They believed that teaching writing should be done through stages. This is in line with the concept of writing is a process. They also believed that the stages of writing that must be passed to make a good writing. In addition, the teacher also realizes the benefits provided by the process approach after implementing it in class. The teacher sees the improvement students' writing improving because of the evaluation process either from the teacher or from friends.

During the implementation of process approach, the teacher is aware of several challenges encountered, namely the limitations of students in developing ideas, and students requires times to finish writing.

\section{REFERENCES}

Adula, H. S. (2018). The practice of process approach in writing classes: Grade eleven learners of Jimma preparatory and Jimma University community preparatory school in focus. International Journal of English and Literature, 9(5), 39-49. https://doi.org/10.5897/ijel2018.1158

Alodwan, T. A. A., \& Ibnian, S. S. K. (2014). The Effect of Using the Process Approach to Writing on Developing University Students' Essay Writing Skills in EFL. International Journal of Linguistic and Communication, 2(2), 147163.

Arici, A. F., \& Kaldirim, A. (2015). The effect of the process-based writing approach on writing success and anxiety of pre-service teachers. Anthropologist, 22(2), 318-327. https://doi.org/10.1080/09720073.2015.11891883

Asriati, \& Maharida. (2013). Improving the Students' Writing Skill by Using Process Writing Approach at the Second Grade Students of SMK Grafika Gowa Makassar. Exposure: Jurnal Pendidikan Bahasa Dan Sastra Inggris, 2(2), 224. https://doi.org/10.26618/ejpbi.v2i2.788

Bayat, N. (2014). The Effect of the Process Writing Approach on Writing Success and Anxiety. Educational Sciences: Theory \& Practice, 14(3), 1133-1142. https://doi.org/10.12738/estp.2014.3.1720

Brown, D. (2004). Language Assessment: Principles and Classroom Practices. San Fransisco State University.

Carolan, F., \& Kyppö, A. (2015). Teaching process writing in an online environment. In J. Jalkanen, E. Jokinen, \& P. Taalas (Eds.), Voices of pedagogical development - Expanding, enhancing and exploring higher education language learning (pp. 13-30). Research-publishing.net. doi:10.14705/rpnet.2015.000285. 
https://doi.org/10.14705/rpnet.2015.000285

Eliwarti, \& Maarof, D. (2014). The Effects of Types of Writing Approaches on Efl Students'Writing Performance. Proceedings of ISELT FBS Universitas Negeri Padang, 112-119.

Faraj, A. K. A. (2015). Scaffolding EFL Students ' Writing through the Writing Process Approach. Journal of Education and Practice ISSN, 6(13), 131-141.

Genlott, A. A., \& Grönlund, Å. (2013). Improving literacy skills through learning reading by writing: The iWTR method presented and tested. Computers and Education, 67, 98-104. https://doi.org/10.1016/j.compedu.2013.03.007

Hadzhikoleva, S., Hadzhikolev, E., \& Kasakliev, N. (2019). Using peer assessment to enhance Higher Order thinking skills. TEM Journal, 8(1), 242247. https://doi.org/10.18421/TEM81-34

Keshta, A. S., \& Harb, I. I. (2013). The Effectiveness of a Blended Learning Program on Developing Palestinian Tenth Graders' English Writing Skills. Education Journal, 2(6), 208. https://doi.org/10.11648/j.edu.20130206.12

Langan, J. (2001). College Writing Skills (6th ed.). The Mc Graw Hill Companies.

Marhaeni, A. A. I. N., \& Dantes, N. (2014). Toward Authentic Language Assessment: A Case in Indonesian EFL Classrooms. The European Conference on Language Learning, 1-0.

Miftah, M. Z. (2015). Enhancing Writing Skill Through Writing Process Approach. Journal of English as a Foreign Language, 5(1), 9-24. url: http://ejournal.iain-palangkaraya.ac.id/index.php/jefl\%0A

Palpanadan, S., Rahim Bin Salam, A., \& Ismail, F. B. (2014). Comparative Analysis of Process Versus Product Approach of Teaching Writing in Malaysian Schools: Review of Literature. Middle-East Journal of Scientific Research, 22(6), 789-795. https://doi.org/10.5829/idosi.mejsr.2014.22.06.21943

Pratiwi, D. I., Faridi, A., \& Hartono, R. (2016). The Implementation of Mind Mapping Strategy to Teach Writing in IELTS Preparation Class. Lembaran IImu Kependidikan, 45(1), 33-41.

Steinke, P., \& Fitch, P. (2017). Minimizing Bias When Assessing Student Work. Research \& Practice in Assessment, 12, 87-95. http://ezproxy.lib.uconn.edu/login?url=https://search.ebscohost.com/login.as px?direct=true \&db=eric \&AN=EJ1168692\&site=ehost-live

Subedi, D. (2016). Explanatory Sequential Mixed Method Design as the Third Research Community of Knowledge Claim. American Journal of Educational Research, Vol. 4, 2016, Pages 570-577, 4(7), 570-577. https://doi.org/10.12691/education-4-7-10

Sun, C., \& Feng, G. (2009). Process Approach to Teaching Writing Applied in Different Teaching Models. English Language Teaching, 2(1), 150-155. https://doi.org/10.5539/elt.v2n1p150

Vonna, Y., Mukminatien, N., \& Laksmi, E. D. (2015). The Effect of Scaffolding Techniques on Students ' Writing Achievement. Jurnal Pendidikan Humaniora, 3(1), 227-233. 